\title{
Comparative Reflections on Hong Kong and Indian Cinema: Identity, Diaspora, and Cosmopolitanism
}

\section{Camille Deprez}

\section{(2) OpenEdition}

12 Journals

Édition électronique

URL : http://journals.openedition.org/chinaperspectives/4856

DOI : 10.4000/chinaperspectives.4856

ISSN : 1996-4617

Éditeur

Centre d'étude français sur la Chine contemporaine

\section{Édition imprimée}

Date de publication : 1 septembre 2009

ISSN : 2070-3449

Référence électronique

Camille Deprez, "Comparative Reflections on Hong Kong and Indian Cinema: Identity, Diaspora, and Cosmopolitanism », China Perspectives [En ligne], 2009/3 | 2009, mis en ligne le 01 septembre 2012, consulté le 28 octobre 2019. URL : http://journals.openedition.org/chinaperspectives/4856 ; DOI : 10.4000/chinaperspectives.4856

Ce document a été généré automatiquement le 28 octobre 2019.

(C) All rights reserved 


\title{
Comparative Reflections on Hong Kong and Indian Cinema: Identity, Diaspora, and Cosmopolitanism
}

\author{
Camille Deprez
}

\section{RÉSUMÉS}

Much research on contemporary Asian cinema is focused within national boundaries or takes an outright international approach, with few comparative studies. Historic and cinematographic similarities between Hong Kong and India since the 1980s allow for a consideration of identity deconstruction and reconstruction in diaspora as seen in some of their films. The notion of vagueness becomes crucial to a nuanced view of the tendency either to withdraw into one's community or turn cosmopolitan.

\section{AUTEUR}

\section{CAMILLE DEPREZ}

Visiting scholar, Cinema and Television Department, Baptist University, Hong Kong; French Centre for Research on Contemporary China (CEFC), Hong Kong; Institut de Recherche sur le Cinéma et l'Audiovisuel (IRCAV), Sorbonne Nouvelle, Paris 